\title{
Biodiversity patterns across the Late Paleozoic Ice Age
}

\author{
Barbara Seuss, Vanessa Julie Roden, and Ádám T. Kocsis
}

\begin{abstract}
The Late Palaeozoic Ice Age (LPIA, Famennian to Wuchiapingian) witnessed two transitions between ice- and greenhouse conditions. These alternations led to drastic alterations in the marine system (e.g., sea-level, habitat size, sea-surface temperature) forcing faunal changes. To reassess the response of the global marine fauna, we analyze diversity dynamics of brachiopod, bivalve, and gastropod taxa throughout the LPIA using data from the Paleobiology Database. Diversity dynamics were assessed regarding environmental affinities of these clades. Our analyses indicate that during the LPIA more taxa had an affinity towards siliciclastic than towards carbonate environments. Deep-water and reefal habitats were more favored while grain size was less determining. In individual stages of the LPIA, the clades show rather constant affinities towards an environment. Those bivalves and brachiopods with an affinity differ in their habitat preferences, indicating that there might have been little competition among these two clades. Origination and extinction rates are similar during the main phase of the LPIA, whether environmental affinities are considered or not. This underlines that the LPIA marine fauna was well adapted and capable of reacting to changing environmental and climatic conditions. Since patterns of faunal change are similar in different environments, our study implies that the changes in faunal composition (e.g., diversity loss during the LPIA; strong increase of brachiopod diversity during the Permian) were influenced by the habitat to only a minor degree but most likely by yet unknown abiotic factors. However, also sea-surface temperature was not the main force driving changes in faunal composition.
\end{abstract}

Barbara Seuss. Friedrich-Alexander-University Erlangen-Nürnberg, GeoZentrum Nordbayern - Section Paleobiology, Loewenichstraße 28,91054 Erlangen, Germany. barbara.seuss@fau.de Vanessa Julie Roden. Friedrich-Alexander-University Erlangen-Nürnberg, GeoZentrum Nordbayern Section Paleobiology, Loewenichstraße 28, 91054 Erlangen, Germany. vanessa.roden@fau.de Ádám T. Kocsis. Friedrich-Alexander-University Erlangen-Nürnberg, GeoZentrum Nordbayern - Section Paleobiology, Loewenichstraße 28, 91054 Erlangen, Germany. adam.kocsis@fau.de

Keywords: glaciation; origination; extinction; affinity; lithology; brachiopods

Submission: 25 November 2019. Acceptance: 15 July 2020.

Seuss, Barbara, Roden, Vanessa Julie, and Kocsis, Ádám T. 2020. Biodiversity patterns across the Late Paleozoic Ice Age. Palaeontologia Electronica, 23(2):a35. https://doi.org/10.26879/1047

palaeo-electronica.org/content/2020/3104-biodiversity-across-the-Ipia

Copyright: July 2020 Paleontological Society.

This is an open access article distributed under the terms of Attribution-NonCommercial-ShareAlike 4.0 International (CC BY-NC-SA 4.0), which permits users to copy and redistribute the material in any medium or format, provided it is not used for commercial purposes and the original author and source are credited, with indications if any changes are made.

creativecommons.org/licenses/by-nc-sa/4.0/ 


\section{INTRODUCTION}

The Late Paleozoic Ice Age (LPIA, approx. $372-254 \mathrm{Ma}$ ) was an outstanding phase in which the Earth underwent remarkable changes (Fielding et al., 2008c). During the Late Paleozoic Ice Age, Pangaea assembled, while mountain ranges formed and the continent extended almost from pole to pole, featuring steep latitudinal temperature gradients and pronounced seasonality (e.g., Fielding, 2008a, 2008b, 2008d; Grossman et al., 2008; Isbell et al., 2003a, 2003b, 2008; Montañez and Poulsen, 2013; Chen et al., 2016). Induced by these changes in the configuration of landmasses and landscape, along with the lowest atmospheric $\mathrm{CO}_{2}$ - and highest $\mathrm{O}_{2}$-levels in the entire Phanerozoic (Berner, 2006), Earth began to cool. Enveloped by two first-order mass extinctions (FrasnianFamennian and end-Permian) (e.g., Sepkoski, 1981, 1984; McLaren, 1982; Muscente et al., 2018), the LPIA represents an exceptional and long-lasting event in Earth's history.

Over the history of the LPIA, glaciation was not uniform. With the first short glacial events recorded from the Famennian (Late Devonian) and the ultimate demise occurring in the Wuchiapingian (upper Permian), the Ice Age lasted more than 100 m.y. After its initiation in the Late Famennian and a phase of brief warming during the early Mississippian, the polar regions of Gondwana were completely glaciated by the middle to late Mississippian. This drop in temperature resulted in a second-order mass extinction with a loss of ca. $28 \%$ of marine genera (Stanley and Powell, 2003) at the Mississippian-Pennsylvanian boundary, which characterized the first peak of the Late Paleozoic glaciation. By the mid-Bashkirian, glaciers retreated until a second major peak of ice formation is reported for the onset of the middle Pennsylvanian. A further phase of deglaciation followed in the Late Carboniferous, which was accompanied by major shifts in marine diversities (for details see Mii et al., 1999; Foote, 2003; Stanley and Powell, 2003; Bambach et al., 2004; Powell, 2005; Brett et al., 2011; Montañez and Poulsen, 2013). Glacial deposits were present during the latest Carboniferous (Fielding et al., 2008a, 2008b, 2008d), but they only became widespread in the early Permian. The LPIA terminated by the midSakmarian deglaciation, with evidence of local ice until 260 my (Wuchiapingian; Montañez and Poulsen, 2013).

The onset of the LPIA changed not only the landscape and sea-level, but also the conditions in the marine environment, such as water tempera- ture and sediment input. As organisms generally favor habitats with specific abiotic factors, the global fauna is forced to react and adapt to the shifting environmental conditions by exploring new niches, migrating, or becoming more generalistic, to mention a few. Sea-level fluctuations often coincide with episodes of biotic turnover, as deepening and shallowing of oceans influences the distribution of marine settings and their structural characteristics; such oscillations directly impact the benthos, plankton, and nekton and eventually lead to biotic turnover (Peters, 2008 and citations therein). These bathymetric fluctuations are therefore suggested to trigger evolutionary radiations and, accordingly, macroevolutionary turnover (e.g., Brett, 1989; Holland et al., 2001; Foote, 2000; Stanley and Powell, 2003; Kiessling and Aberhan, 2007; Peters, 2008; Holland, 2012).

Temperature fluctuations during the Ice Age impact the fauna (and flora) itself, especially organisms with narrow temperature-tolerance. In general, taxa living during the LPIA are considered to have been long-ranging and geographically widespread (Stanley and Powell, 2003; Powell, 2005, 2007), resulting in a dampening effect on evolutionary rates (e.g., Raup and Sepkoski, 1982; Sepkoski, 1998; Stanley and Powell, 2003; Bonelli and Patzowksy, 2008). Indeed, the rates of origination and extinction were suggested to be depressed, and global diversity remained roughly stable during the Upper Carboniferous (Stanley and Powell, 2003; Foote, 2006). Alroy et al. (2008) even found an overall decrease in the global genus-level diversity throughout the Upper Carboniferous. The loss of specialized taxa and the dominance of generalists (i.e., those that are less restricted to a specific environment, Powell, 2005; Stanley, 2007) can be a likely reason for this phenomenon.

For example, reefs are known to have generated most of the diversity (Kiessling et al., 2010). Also, the grain size affects the distribution and settlement of species - when other parameters are stable but particle size increases, there is a decrease in species richness and abundance (McLachlan, 1996). This might be attributed to a limit in burrowing performance (Alexander et al., 1993) or a limited body size (McLachlan et al., 1996). We consider that the biota in different environmental settings show varying reactions to changes throughout the LPIA, as these settings are differently influenced by the effects of glaciation and deglaciation. Here we investigate faunal turnover throughout the LPIA and assess whether affinities towards environmental factors have influ- 
enced global paleobiodiversity and turnover rates. To test our hypothesis that fauna in different environments is differently affected by the Ice Age, we calculate the time series of diversity dynamics of LPIA fauna using the occurrence dataset of the Paleobiology Database and analyze it in subsets corresponding to affinities towards a certain lithology, grain size, bathymetry, and reefal vs. nonreefal environment. We base the selection of the clades on Sepkoski's evolutionary faunas (Sepkoski, 1981, 1984).

\section{MATERIAL AND METHODS}

We downloaded fossil occurrence data from the Paleobiology Database (PBDB; paleobiodb.org) on May 24, 2018 and on May 14, 2019 (Appendix 1). Two additional datasets gathered from the literature and including own observations are integrated into the LPIA time frame. These data contain the fauna from the Desmoinesian (Pennsylvanian, Upper Carboniferous) Buckhorn Asphalt Quarry Lagerstätte in Oklahoma (compiled for Seuss et al., 2009) and from the Virgilian (Pennsylvanian, Upper Carboniferous) Finis Shale in Northern Texas (compiled for Roden et al., 2020). The dataset comprises occurrences from the Ordovician to Permian (specific time frame for the study: Famennian to Wuchiapingian). We restricted the clades to benthic, marine members of Sepkoski's evolutionary faunas (compare Sepkoski, 1981, 1984, 1990; Muscente et al., 2018; Rojas et al., 2020), only including brachiopods, bivalves, and gastropods. These are taxonomically well studied and have an extensive record in the PBDB. The other major classes of Sepkoski's evolutionary faunas (compare Sepkoski, 1981) are excluded; these are cephalopods and osteichthyes, both being nektic, and crinoids and trilobites because both are not well represented in the PBDB during the LPIA.

We calculate gamma-level diversities, per capita extinction, origination, and total turnover (sum of origination and extinction) rates. Diversity is presented per stage as corrected sampled-in-bin genus richness (CSIB), which is the number of genera in each time bin, corrected using the threetimer sampling completeness of Alroy (2008). Additionally, we investigate the affinity of every genus towards environmental factors. Environmental affinity is the preferred environment of a genus, calculated using the distribution of occurrences across the environments (Foote, 2006; Kiessling and Aberhan, 2007; Kiessling and Kocsis, 2015). A binomial test is applied with an alpha value of 0.5 to determine environmental affinity. The selected environments are lithology: carbonates vs. siliciclastics, reef vs. non-reef, bathymetry: shallow vs. deep, grain size: coarse- vs. fine-grained. With special focus on the LPIA, the lithologies are combined into the categories 'carbonates' and 'siliciclastics' based on Füchtbauer (1988) and own extensions (Munnecke, personal commun., 2019) to include as much data as possible (Appendix 2). We also present the total number of occurrences as well as genera with an affinity for each environment and clade and the ratio of occurrences for each environment pair (Table 1).

Biases in the fossil data derive from various factors like taphonomic variations, sampling strategies, or methodological effects. Also, the available rock surface, the degree of preservation of fossils, or the type of deposits, among other factors, lead to distortion of results and, accordingly, their interpretation (e.g., Koch and Sohl, 1983; Cherns and Wright, 2000, 2009; Kowalewski and Hoffmeister, 2003; Wright et al., 2003; Alroy et al., 2008; Cherns et al., 2008; McGowan and Smith, 2008). To reduce such issues, we standardize the data by subsampling using shareholder quorum subsampling with a quorum of 0.6 (Alroy, 2010). All analyses are carried out with $\mathrm{R}$ Version 3.5.0 (R Core Team, 2016) using the divDyn package (Kocsis et al., 2019). The code for the analyses in $R$ is provided in Appendix 3.

All measures are calculated for both the entire dataset and the data of individual fossil groups (i.e., brachiopods, bivalves, and gastropods). Occurrences that lack the following information are excluded prior to statistical analysis: stratigraphic stage, lithological information, non-informative genus (i.e., those with ? and those where no genus name was provided, e.g., only the family was listed). In total, the LPIA dataset contains 79,234 occurrences identified to the genus or species level, representing 308 bivalve, 380 gastropod, and 1105 brachiopod genera for analysis. To evaluate how data entry into the PBDB may influence results from statistical analyses, the number of references per stage is also provided. Correlations are calculated between the number of occurrences, genus richness, and subsampled genus richness with the number of references per stage for the LPIA dataset as well as the entire Phanerozoic (Appendix 4). To discern possible relationships between diversity patterns and abiotic factors, seasurface temperatures (SST) based on Song et al. (2019) are included in the analyses. All correlation tests use Spearman's rank correlation coefficient. Additionally, we test how disproportionate sampling 
TABLE 1. Affinity counts and ratios of occurrences and clades in total and grouped by environmental factors for the LPIA. TO: total occurrences; env1, env2: first and second environment of the pair respectively; GA: genera with affinity to the one or the other environment. Only genera with stage information are included.

\begin{tabular}{llcc}
$\begin{array}{c}\text { Total occurrences } \\
\text { Total genera }\end{array}$ & \multicolumn{1}{c}{79234} & & \\
\hline \multicolumn{1}{c}{ Phylum } & \multicolumn{1}{c}{ Class } & Occurrences & Genera (G) \\
\hline Mollusca & Bivalvia & 10368 & 308 \\
Mollusca & Gastropods & 9620 & 380 \\
Brachiopoda & all & 59246 & 1105 \\
& Lingulata & 649 & 20 \\
& Rhynchonellata & 29811 & 524 \\
& Strophomenata & 28473 & 551 \\
& Chileata & 52 & 3 \\
& Craniata & 261 & 7 \\
& & & 1793
\end{tabular}

or data entry biases the results. Especially for the Permian, M. Clapham and his working group entered and authorized a great number (1597) of references (total dataset: 7234; November 18, 2019), comprising $22 \%$ of all occurrences. To evaluate what is informally known as the "Claphameffect" (an artifact caused by above average effort in data entry), we remove these entries (Appendix 5) from the dataset and compare our analyses with those of the complete dataset.

\section{RESULTS}

The number of occurrences (Table 1) (Appendix 6A) illustrates that bivalves and gastropods are distinctly less common compared to brachiopods. The proportion of brachiopods among the entire fauna is $>0.75$ throughout most of the LPIA, except for the main phase of the Ice Age between the Serpukhovian and Kasimovian. Only the gastropods in the Moscovian contribute markedly to the number of occurrences. Mollusk occurrence counts show a more constant trajectory throughout the entire Ice Age, while brachiopod occurrences increase dramatically from the latest Carboniferous onwards and peak in the Kungurian and Wuchiapingian.

Subsampled genus richness (without considering affinities) features a similar pattern (correlation of genus richness and number of occurrences: Spearman's $\rho: 0.88 ; \mathrm{p}<2.2 \mathrm{e}-16$ ) (Figure 1): Brachiopods show highest genus richness except for the Moscovian and Gzhelian and are especially dominant in the Permian. Both gastropods and bivalves have generally lower diversities through- out the LPIA. The Permian is characterized by a slight increase in bivalve and gastropod diversity.

Among the four environmental factors, the occurrences (all clades) of carbonates, non-reefal, shallow marine, and fine-grained deposits are distinctly higher compared to their environmental counterpart (Table 1). However, our analysis reveals that more taxa (i.e., genera with affinity) had a preference towards siliciclastics compared to carbonates. Reefal and deeper water settings contain distinctly more genera than non-reefal and shallow marine settings, respectively, while the number of genera that prefer an either coarse or fine-grained deposit is nearly the same. The proportion of genera with an affinity among all genera reveals same preferences except for the grain size (here fine-grained deposits are slightly favored now).

The ratio of total number of occurrences (TO env1:TO env2) in reefal vs. non-reefal environments as well as in coarse-grained vs. fine-grained environments is relatively uniform for all three clades (Table 1). About twice as many occurrences are reported from carbonate settings than siliciclastic settings, which are also reflected in the ratios among gastropods and brachiopods. Bivalves, however, are reported more frequently from siliciclastic settings. Regarding bathymetry, there is also a deviation from the expected distribution of occurrences for bivalves and gastropods, both of which occur more frequently in shallow settings than expected from the overall distribution.

When investigating the genera with affinity individually, we find that more bivalve genera have an affinity for siliciclastics, non-reefal, and fine- 
TABLE 1 (continued).

\begin{tabular}{|c|c|c|c|c|c|c|}
\hline & & & $\begin{array}{c}\text { Total } \\
\text { occurrences (TO) }\end{array}$ & $\begin{array}{l}\text { Genera with } \\
\text { affinity (GA) }\end{array}$ & GA:G & $\begin{array}{l}\text { TOenv1: } \\
\text { TOenv2 }\end{array}$ \\
\hline \multirow[t]{9}{*}{ Lithology } & carbonate & all & 46541 & 458 & 0.26 & \multirow{2}{*}{1.90} \\
\hline & siliciclastics & all & 24517 & 519 & 0.29 & \\
\hline & carbonate & Bivalvia & 4282 & 41 & 0.13 & \multirow{2}{*}{0.82} \\
\hline & siliciclastics & Bivalvia & 5241 & 156 & 0.51 & \\
\hline & carbonate & Gastropoda & 6172 & 129 & 0.34 & \multirow{2}{*}{2.03} \\
\hline & siliciclastics & Gastropoda & 3036 & 68 & 0.18 & \\
\hline & carbonate & Brachiopoda & 36087 & 288 & 0.26 & \multirow{2}{*}{2.22} \\
\hline & siliciclastics & Brachiopoda & 16240 & 295 & 0.27 & \\
\hline & unknown & all & 8171 & & & \\
\hline \multirow[t]{9}{*}{ Reef/non-reef } & reef & all & 5377 & 326 & 0.18 & \multirow{2}{*}{0.18} \\
\hline & non-reef & all & 29928 & 242 & 0.13 & \\
\hline & reef & Bivalvia & 625 & 34 & 0.11 & \multirow{2}{*}{0.15} \\
\hline & non-reef & Bivalvia & 4035 & 69 & 0.22 & \\
\hline & reef & Gastropoda & 624 & 51 & 0.13 & \multirow{2}{*}{0.15} \\
\hline & non-reef & Gastropoda & 4191 & 53 & 0.14 & \\
\hline & reef & Brachiopoda & 4128 & 241 & 0.22 & \multirow{3}{*}{0.19} \\
\hline & non-reef & Brachiopoda & 21702 & 120 & 0.11 & \\
\hline & unknown & all & & & & \\
\hline \multirow[t]{9}{*}{ Bathymetry } & deep & all & 10712 & 336 & 0.19 & \multirow{2}{*}{0.44} \\
\hline & shallow & all & 24587 & 239 & 0.13 & \\
\hline & deep & Bivalvia & 987 & 50 & 0.16 & \multirow{2}{*}{0.27} \\
\hline & shallow & Bivalvia & 3673 & 57 & 0.19 & \\
\hline & deep & Gastropoda & 945 & 61 & 0.16 & \multirow{2}{*}{0.24} \\
\hline & shallow & Gastropoda & 3868 & 47 & 0.12 & \\
\hline & deep & Brachiopoda & 8780 & 225 & 0.20 & \multirow{2}{*}{0.52} \\
\hline & shallow & Brachiopoda & 17046 & 135 & 0.12 & \\
\hline & unknown & all & 43935 & & & \\
\hline \multirow[t]{9}{*}{ Grain size } & coarse & all & 8169 & 272 & 0.15 & \multirow{2}{*}{0.47} \\
\hline & fine & all & 17292 & 296 & 0.17 & \\
\hline & coarse & Bivalvia & 1248 & 42 & 0.14 & \multirow{2}{*}{0.42} \\
\hline & fine & Bivalvia & 2967 & 84 & 0.27 & \\
\hline & coarse & Gastropoda & 1075 & 55 & 0.14 & \multirow{2}{*}{0.38} \\
\hline & fine & Gastropoda & 2813 & 56 & 0.15 & \\
\hline & coarse & Brachiopoda & 5845 & 175 & 0.16 & \multirow{2}{*}{0.51} \\
\hline & fine & Brachiopoda & 11512 & 156 & 0.14 & \\
\hline & unknown & all & 53773 & & & \\
\hline
\end{tabular}

grained environments with a tendency towards shallow marine habitats. More gastropod genera have a preference for carbonates and deep-water settings. Whether the setting is reefal or not as well as the grain size is of less relevance. Except for the lithology (no clear preference), more brachiopod genera had a favor for deep and reefal environ- ments, with some tendency towards coarsegrained settings. Throughout the stages, there is some minor fluctuation in the genus richness (Appendix 7) for all clades. As for the CSIB without affinities, brachiopods have a large influence on the overall diversity. 


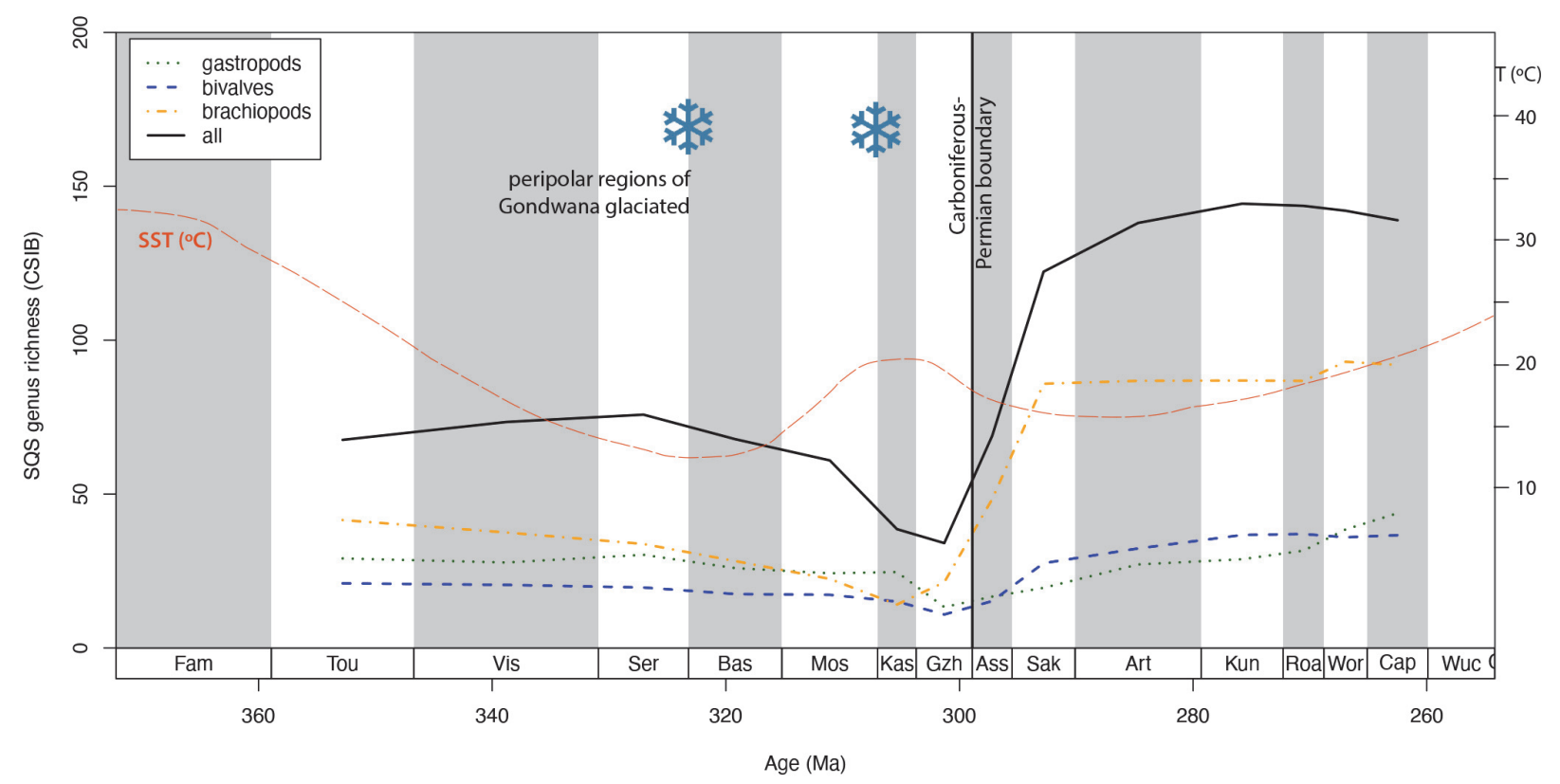

FIGURE 1. Genus richness (corrected sampled-in-bin diversity, CSIB) during the LPIA with all clades combined, and gastropods, bivalves, and brachiopods plotted separately. Mean sea-surface temperature (SST) after Song et al. (2019). The two main phases of the glaciation indicated with snowflakes.

Without considering different environments, the overall tendency of origination rates is similar for all three clades (Appendix 6B), with gastropods having lower rates in the Permian compared to brachiopods and bivalves, and bivalves starting at a pronounced low in the Tournaisian. Origination rates are highest in the Early Carboniferous, followed by a sharp descent in the Serpukhovian. After a slight increase, the rates decrease further, with the lowest rates in the Kasimovian and Gzhelian. This drop is succeeded by an increase in the early Permian and another decline towards the end-Permian mass extinction.

Extinction rates (Appendix 6C) are highest at the beginning of the LPIA (Tournaisian and Viséan) and especially towards the onset of the end-Permian mass extinction. These rates are relatively constant throughout the LPIA, and the brachiopods, gastropods and bivalves do not show large differences.

At the beginning of the LPIA, total turnover (Figure 2) in brachiopods is noticeably higher than in bivalves and gastropods. This turnover changes after the Viséan, when the rates of all clades decrease distinctly to 0.35 and less and remain low throughout the LPIA. Brachiopod turnover rates are higher in most stages compared to bivalves and gastropods.
It is striking that the overall pattern of originatin rates in the individual environments, and when all environments are combined, are similar (Appendix 8; Appendix 9). Highest rates are in shallow and non-reefal milieus. This pattern is also present in the extinction rates (Appendix 10; Appendix 11) in different environments when compared to the overall rate, with remarkably high rates of extinction in shallow-water settings in the Tournaisian and an exceptional increase of extinction rates in the Viséan in non-reefal settings. Turnover rates remain low during the main phase of the LPIA (from the Serpukhovian onwards; Figure 3; Appendix 12) and are similar in the different environments. Highest rates of faunal turnover occur in the Early Carboniferous and increase towards the endPermian mass extinction.

We find stage-level sampling completeness to be fairly high (Appendix 13), exceeding $70 \%$ in most of the stages. According to the Wilcoxon rank sum test, there is no significant difference between the Carboniferous and Permian interval during the LPIA $(p=0.56)$.

Our data show an extreme rise of brachiopod diversity in the Permian. References per stage show that the brachiopod references are extremely common during the Permian (Appendix 14). Appendix 15 lists the correlation of number of occurrences, genus richness, and subsampled 


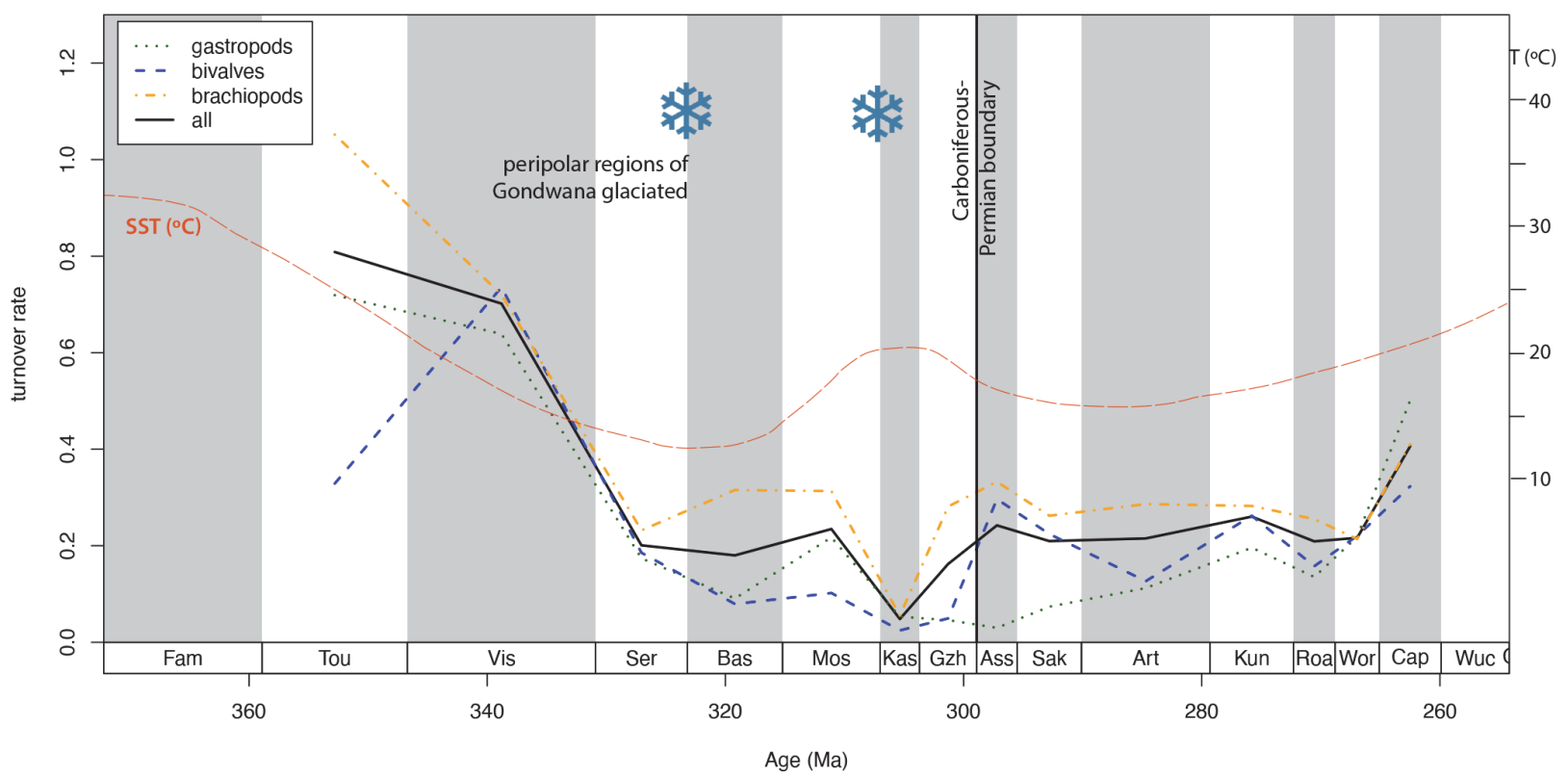

FIGURE 2. Turnover rates during the LPIA with clades plotted individually and merged. Mean sea-surface temperature (SST) after Song et al. (2019). The two main phases of the glaciation indicated with snowflakes.

genus richness each with the number of references per stage. All results are significant $(p<0.05)$. Especially the number of occurrences shows high correlations with similar values for all three clades (LPIA and Phanerozoic). While genus richness (both timeframes) is high and similar for brachiopods and bivalves, gastropods have lower correlation values. For the subsampled genus richness, bivalves and brachiopods indicate higher correlation than gastropods, which is extremely pronounced for the LPIA.

There is a distinct fluctuation of the proportion of the total number of references per clade during the Carboniferous, while the Permian demonstrates a smoother pattern (Appendix 16). The proportions of gastropods and brachiopods are much lower than those of brachiopods, i.e., brachiopods are represented to a higher degree in the Carboniferous and the Permian. Appendix 17 illustrates the extraordinary difference in brachiopod occurrences during the Permian with and without data authorized by $\mathrm{M}$. Clapham. The same effect can be seen for the genus richness (Appendix 18) and for the subsampled genus richness (Appendix 19). The differences are not only distinct for brachiopods but also for gastropods and bivalves, although to a minor degree.

There is no relationship between genus richness (CSIB) and sea-surface temperature (Pearson's correlation $=0.09, p=0.76)$, nor between
SST and turnover (Pearson's correlation $=0.52, p$ $=0.06$ ).

\section{DISCUSSION}

\section{Dynamics During the LPIA}

Occurrence patterns. Differences in the number of occurrences can be explained by, for example, length of the stage (e.g., the Viséan is comparatively long), sampling bias (e.g., sampling intensification, preserved rock volume, availability), primary shell mineralogy, and preservation of taxa, or preferences by contributors of the PBDB (discussed in separate paragraph) (e.g., Cherns and Wright, 2000, 2009; Kowalewski and Hoffmeister, 2003; Wright et al., 2003; Alroy et al., 2008; Cherns et al., 2008; McGowan and Smith, 2008). In addition, water temperature impacts the physiological functioning of aquatic fauna (e.g., Pörtner, 2002, 2010), and oscillations in water temperature might increase or reduce available habitat and, in consequence, abundance and/or diversity.

Comparing our data with Stanley and Powell's (2003) results, we see that despite the years that have passed and the use of data from Sepkoski (Stanley and Powell, 2003) versus PBDB (this study), the overall trend is still present. The highest number of occurrences is still in the Viséan followed by a relative low during the succeeding Carboniferous and a pronounced increase throughout the Permian; even the slight Moscovian rise is 


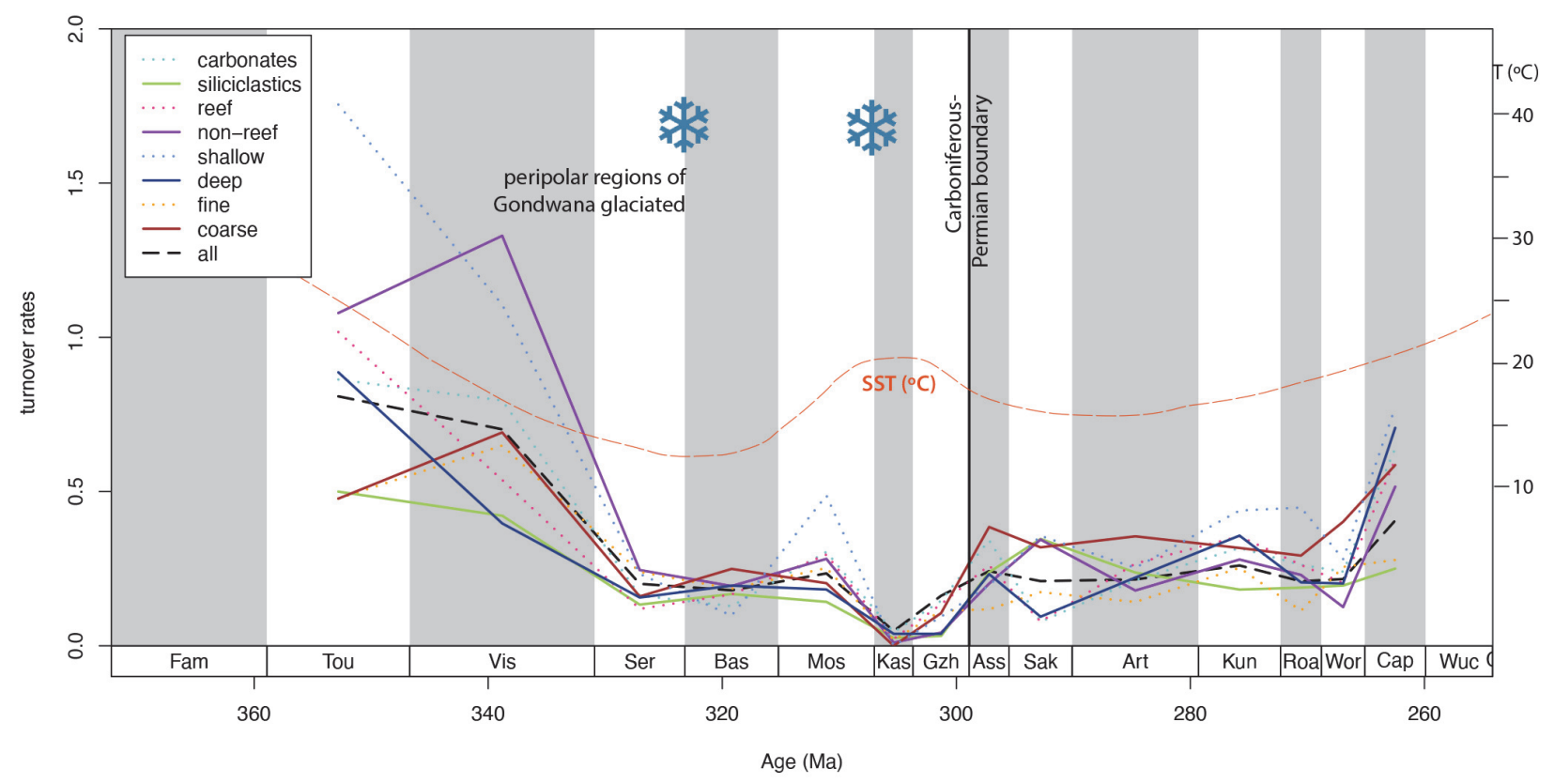

FIGURE 3. Turnover rates for the compared environments merged (also see Appendix 12 with single panels for environments). Mean sea-surface temperature (SST) after Song et al. (2019). The two main phases of the glaciation indicated with snowflakes.

recorded in both analyses. At first glance, this might be surprising, considering that over the past nearly 20 years (Sepkoski's data derive from 2002), sampling and data entry into the PBDB would have modified available data sets, at least to some degree (e.g., by sampling intensity, sampling in remote or places where the entry is prohibited, revision of taxonomy). Yet, it underlines the stability of the data we gather from the fossil record. However, occurrence counts are susceptible to sampling heterogeneity and thus should not be taken as direct descriptors of biotic changes during the LPIA.

Genus richness. The uniformity in genus richness (Figure 1) during most of the Carboniferous mirrors the stability of the fauna after recovery from the Frasnian-Famennian mass extinction, which indicates adaption to the ice-house conditions and its consequences. However, the relatively higher rates of origination at the beginning and the demise of the LPIA (Appendix 5) demonstrate that the fauna was undergoing changes in composition until stability set in. It is obvious that the global environmental changes during the LPIA were responsible for the reorganization of the fauna. The occurring environmental conditions caused a tight interaction between onset of glaciation and recovery of the fauna in the Latest Devonian and Early Carboniferous, as the latter had to concentrate on adaptation.
However, the lack of correlation between the newly modelled SST curve (Song et al., 2019) and genus richness does not mirror this, and, therefore, sealevel fluctuations were not the main drive of turnover.

Clades evaluated separately show an overall similar trend throughout the LPIA, with lowest diversity throughout the Carboniferous and an increase during the early Permian. Previously observed patterns of low diversity in the Carboniferous (Stanley and Powell, 2003) are corroborated by our study. In conclusion, our data support earlier studies that the fauna during the LPIA was reduced to well adapted taxa that could cope with the changing conditions during the Ice Age (Stanley and Powell, 2003; Powell, 2005; Foote, 2006; Alroy et al., 2008; Bonelli and Patzowsky, 2008). Brachiopods dominate the fauna and strongly diversify during the Permian, while gastropods and bivalves have less impact and diversify only to a minor degree. Sampling completeness is not significantly better in the Permian; thus, this cannot explain the difference in genus richness when compared to the Carboniferous. For gastropods and bivalves, the slight rise in diversity might simply reflect more stable environmental conditions along with newly developing habitats after the severe glacial phases of the LPIA, hence enhancing diversification. How- 
ever, brachiopods tell a different story, which is discussed below.

Origination, extinction, and turnover rates. The initially decreasing and then continuously low rates of origination and extinction indicate that the brachiopod, bivalve, and gastropod taxa were well adapted to climatic and environmental changes throughout the main glacial periods of the LPIA (e.g., Stanley and Powell, 2003; Powell, 2005; Foote, 2006; Alroy et al., 2008; Bonelli and Patzowsky, 2008). This also implies that the taxa had enough time to adjust to the climatic and environmental changes. The distribution of landmasses and shifts in the global climate resulted in an increase of the geographic range and niche breadth of taxa (Stanley and Powell, 2003), which would have allowed populations to disperse along these niches, eventually raising the average size and stability of each population without the need of diversification. Changes in faunal diversity as a response to transgression and regression are likely idiosyncratic, as there are numerous additional factors that need to be taken into account when considering the habitat and geographic distribution of fauna (e.g., shape of the coast, steepness of the shelf, direction of sea-level change or topography; Holland, 2012). The pattern of turnover is possibly a stratigraphic artifact and might not necessarily reflect true turnover driven by sea-level change alone (e.g., Dunhill at al., 2014; Jarochowska et al., 2018), but it is accompanied by a complex combination of factors that complicate interpretation (compare Holland, 2012). In contrast to our results, Stanley and Powell (2003) found turnover rates to be low until the Sakmarian. The differences probably are caused by our more extended dataset and new statistical methodology (i.e., subsampling).

Even though there is no relationship between SST and turnover rates during the LPIA, it is still possible that SST becomes more important during the Permian in the aftermath of the severe glaciations in combination with other abiotic factors.

\section{Affinities Towards Environmental Factors}

Substrate affinity contributes to macroevolution as the main force driving short-term fluctuations in marine diversity (Foote, 2006). Turnover rates of genera with certain environmental affinities vary: for example, genera with an affinity to siliciclastic, offshore, and level-bottom settings have lower turnover rates compared to taxa with an affinity towards carbonates, onshore settings, and reefs (Kiessling and Aberhan, 2007). Brachiopods are the least conservative among the marine fauna, and the Carboniferous is considered as a period of low niche conservatism (Hopkins et al., 2014). There are more than twice as many genera in the Paleozoic with an affinity towards carbonate settings than those that prefer a siliciclastic environment, which is suggested to represent a general biotic feature (Foote, 2006) and underlines the linkage between fauna and substrate. However, Foote's (2006) finding conflicts with our results spanning the LPIA only, when the number of genera in carbonates is approximately $10 \%$ lower compared to siliciclastic settings (Appendix 6). Reasons for this might be the different methodology and data available for the studies (compare Foote, 2006) but also the fact that the LPIA is an extraordinary phase in Earth's history, which is not comparable with the entire Paleozoic. For the LPIA in North America, a collapse of carbonate platforms is suggested to cause a low local diversity, while an increase in siliciclastic environments was observed (Balseiro and Powell, 2020). This pattern is not reflected in our study, as genus richness in carbonates indeed is diminished but it is not dramatically different in both lithologies. Both settings show a similar decrease in genus richness during the second main phase of glaciation (a low in the Kasimovian: carbonates, and Gzhelian: siliciclastics) followed by a pronounced increase in genus richness in both environments. The latter is even more pronounced in carbonate settings. Thus, the suggested collapse of North American carbonate platforms is not evident globally, which implies that the regional might be suppressed by the global signal.

Our results show that the affinities differ among the three clades (compare Table 1). This implies that the clades were largely set in own niches / habitats without being in great competition with each other. Among those with affinities, bivalves and brachiopods did not share the same preferences. These clades might only have some overlap in lithology, as brachiopods do not show a clear preference towards carbonates or siliciclastics. Considering different stages (Appendix 7), there is some fluctuation in the grade of affinity, but the overall affinity towards an environment is constant with a few exceptions only (i.e., water depth for bivalves and grain sizes for brachiopods). This relative stasis of preferences for an environment supports the assumption that most taxa were adapted generalists throughout the main phase of the LPIA.

In many cases the number of occurrences does not reflect the number of genera with an affinity towards an environment. For example, there are 
five times as many brachiopod occurrences in nonreefal settings compared to reef settings, but only half as many genera have a non-reefal affinity. Gastropods are nearly three times as common in fine-grained deposits compared to coarse-grained settings, but the number of genera with an affinity to one or the other environment is nearly the same. Also, bivalves occur more frequently in siliciclastics than expected by the overall distribution. And bivalves and gastropods are about four times more abundant in shallow waters, whereas only about twice as many occurrences (all taxa) are from the same environment. We conclude as the number of occurrences of a genus in a certain environment is linked to its affinity to that environment, that many genera did not have strong affinities. The lack of strong preferences during the LPIA suggests that taxa could adapt to changing environmental conditions.

\section{Origination, Extinctions, and Turnover}

General results. Our results show that throughout the LPIA, there is some fluctuation in origination rates while extinction rates comparatively vary less. Both rates though are low (especially extinction) compared to the Phanerozoic averages, therefore turnover is remarkably low. Thus, we conclude that taxa in the Carboniferous adapted well to glacial conditions, which is in accordance with the results of Stanley and Powell (2003).

Individual environments. Evolutionary rates are indirectly controlled by environmental factors (Kiessling and Aberhan, 2007) and thus, for different environments (carbonate vs. siliciclastic; reef vs. non-reef; onshore vs. offshore), differing rates of origination/extinction occur (Hopkins, 2014 and citations therein). Our results do not entirely confirm these processes. Indeed, there are different rates of origination and extinction, but since rates throughout the main phase of the LPIA are extremely low, the variation among environments is not high. The distinctly higher origination rates at the beginning of the LPIA might still represent continued recovery from the Frasnian-Famennian mass extinction, when the fauna entered and adapted to open niches. Similarly, higher origination rates are also seen during the AsselianSakmarian, i.e., the stages that follow the second severe glaciation of the LPIA, again with the opening of new niches.

Extinction rates remained low for a long time after the second phase of severe glaciation. The well-adapted taxa could enter newly opening niches. The rate of extinction indicates a moderate background-extinction only. Pronounced higher extinction rates occur in the Capitanian and may indicate increasing environmental change and variation within the marine realm. This might have been caused, for example, by increasing influence of the continent (e.g., weathering), the weather itself (e.g., aridity producing more dust being transported into the sea), but also by sea-level changes I tectonic uplift of the continent due to the melting of the icecaps. There is no indication, however, that this increase in extinction rates is a precursor of the coming mass extinction at the PT-boundary.

Turnover rates throughout the Carboniferous become similar after the Viséan and only show slightly more variation in the Permian. However, rates are still low for both intervals, deriving from the low origination and extinction rates. Deep water settings are thought to be influenced to a higher degree than previously assumed (e.g., Yasuhara et al., 2008), resulting in major faunal collapses and greater turnover. This statement is valid for the Tournaisian and with limitations for the Viséan, but not afterwards, when the rates, for most stages, nearly converge and follow a similar pattern. Since there are no major differences in the rates of siliciclastics and carbonates from the Serpukhovian onward, we conclude that lithology did not significantly affect the taxa and thus, was not the main driver. The other environmental factors (grain size and reef / non-reef) are also of limited influence. This supports the impression of faunal stability due to adaption of taxa throughout the LPIA. It also underlines that the LPIA was an outstanding phase in Earth's history.

\section{Permian Rise of Brachiopods}

Especially during the Permian, brachiopods dominate the genus richness of the studied fauna. It was a complex interplay of extinction and origination that drove brachiopod and bivalve diversity, not competition among these clades, that led to a rapid and pervasive filling of ecological niches after the end-Permian mass extinction by bivalves, eventually leading to their post-Paleozoic dominance (Liow et al., 2015; Reitan and Liow, 2017). There is strong indication that bivalve and brachiopod dynamics are causally linked, but these causes are yet unknown (Liow et al., 2015). The increase of brachiopod diversity in the Permian differs distinctly from that of the bivalves and gastropods, raising the question of the driver of genus richness in this period. Sampling rates of brachiopods and bivalves are found to strongly correlate 
(Liow et al., 2015), indicating a true ecological signal.

Species diversity is driven mainly by abiotic factors (e.g., landscape, climate, and food supply; e.g., Benton, 2009; Antell et al., 2020), and despite their external similarity (e.g., Arapov et al., 2010), bivalves and brachiopods have differing diversification patterns. A prominent internal feature of brachiopods is the multi-purpose lophophore (Richardson, 1986), which is used to create active and passive water currents for respiration, excretion, and reproduction (e.g., Atkins, 1956; Bullivant, 1968; Carlson, 2016). Brachiopods in the Paleozoic are likely to have had a low metabolic rate and highly efficient digestion (e.g., Richardson, 1986; Clark Rhodes and Thompson, 1993; Payne et al., 2014). If the vast majority also was stenotopic, as are living brachiopods (Clapham and Bottjer, 2007), this will have increased the flexibility of the LPIA-brachiopods to react to environmental changes.

The Upper Carboniferous is known as a period of low diversity among the phytoplankton and reduced primary production (Rigby and Milsom, 2000; Mullins and Servais, 2008; Lei et al., 2013). However, a "phytoplankton blackout" as concluded by Riegel $(2008$, p. 73 ) was not existent (e.g., Seuss et al., 2009; Lei et al., 2013), and a lack of cysts may simply be due to non-fossilizable plankton (Rigby and Milsom, 2000; Servais et al., 2006; Servais, 2015; Martin and Servais, 2020). In the Late Paleozoic, marine productivity increased (Clapham and Bottjer, 2007; Martin et al., 2008; Allmon and Martin, 2014), but many elements of the Permian phytoplankton may still be unknown (e.g., picoplankton; Mullins and Servais, 2008; Lei et al., 2013). However, peaks in pseudoplankton diversity are recorded for the Permian (Wignall and Simms, 1990). Since food is captured with the lophophore, the bauplan might be of relevance. While plectolophus brachiopods do not benefit from high concentrations in phytoplankton (Clark Rhodes and Thompson, 1993), this might be different for other species. The lophophores are covered with filaments and cilia and actively create currents to gather food. Comparatively strong currents enhance the chances of capturing phyto- and zooplankton. The shape of some brachiopod shells improves the creation of passive feeding and respiration flows within the shell; when conditions are favorable, the passive flows are sufficient, but as soon as conditions deteriorate, the brachiopod uses its lophophore for actively produced flows (Shino et al., 2009; Shiino, 2010). At the Sakmar-
ian-Artinskian boundary, the thermohaline circulation along the northwestern margin of Pangaea was strongly enhanced (Beauchamp and Baud, 2002), oxygenizing the water. This would have supported the use of passive flows in brachiopods saving energy. The flexible stalk will have supported gathering food but also escaping from burial (Richardson, 1986). The combination of the capability to survive at low oxygen levels, which often occur in the aftermath of sea-level rise as modeled for the Permian (Harper and Moran, 1997), and lower demands because of their lower metabolic rate, might partly explain the diversification of brachiopods. Dissolved oceanic oxygen strongly influences and regulates geochemical and metabolic processes in marine animals (e.g., Richards, 1957; Stramma et al., 2008; Long et al., 2016). With increasing concentration of atmospheric oxygen (Song et al., 2019) and the interplay between the atmospheric $\mathrm{O}_{2}$ and the dissolved oceanic oxygen, brachiopods might have benefitted more than bivalves and gastropods. Besides the increase in diversity, it is also striking that brachiopods represent the most successful calcifying clade for most of the Paleozoic (Eichenseer et al., 2019). Temperature and the $\mathrm{Mg} / \mathrm{Ca}$ ratio affect growth rates, as well as the skeletal composition and production and the acquisition of biominerals of numerous calcifiers in marine settings (Eichenseer et al., 2019 and references therein). During the Permian, sea water was highly enriched in $\mathrm{CaCO}_{3}$. Extremely high or even hypersaturation would have favored calcitic brachiopods over aragonitic bivalves and gastropods and might contribute to the increase in brachiopod diversity. With the end of the LPIA, new niches developed, and not only brachiopods but also bivalves and, to some degree, gastropods diversified and inhabited these places (e.g., infaunal mode of life) in the Mesozoic (Clapham and Bottjer, 2007). Thus, the latter also benefitted from changing environmental conditions and its consequences but only took advantage after the endPermian mass extinction when brachiopods suffered dramatically.

The rise of the Permian brachiopods is evident from our results, but is the extreme rise of brachiopods an ecological signal or not? To evaluate this signal, it is necessary to consider the shell material, in addition to factors discussed above, as high-Mg calcite and aragonite are more prone to dissolution than low-Mg calcite (Wright and Cherns, 2004). Several studies have investigated the (early) diagenetic loss of aragonitic fauna (largely bivalves and gastropods) and its degree 
(Cherns and Wright, 2000; Wright et al., 2003; Cherns et al., 2008; Cherns and Wright, 2009; Jordan et al., 2015; and references therein). Cherns et al. (2008) found skeletal lagerstätten to contain a rich molluscan assemblage of originally aragonitic taxa contrasting with the faunal composition in non-silicified assemblages. Many of these occurrences (i.e., skeletal lagerstätten) are entered into the PBDB, although they are not necessarily indicated as such, but obviously contributing to the completeness of the PBDB fossil record. However, environmental factors also influence the presence and abundance of a taxon in a specific habitat already during its lifetime, and not only taphonomic processes that occur after the death of the specimen (Wright and Cherns, 2008). It is thus possible that a specific taxon simply was not present. Kidwell (2005) thus concluded that shell composition has little effect on macroevolutionary biodiversity.

Since foundation of the PBDB, there is continuous input of data. However, some researchers and working groups have put more effort in data entry (and authorization) than others. Thus, there is a possible bias towards certain clades and taxa and/or geological time periods that mirrors the scientific preference of the enterer/authorizer. An example is $\mathrm{M}$. Clapham and his working group. These possibly overrepresented authorizations are informally known as "Clapham-effect". Our results (Appendix 17; Appendix 18; Appendix 19) indicate that this effect seems to favor brachiopods throughout the Permian; however, also the occurrence of gastropods and bivalves is markedly reduced without Clapham-authorizations. Without these authorizations, a vast amount of data would be missing in the PBDB as many taxa are not recorded by other enterers. Likewise, P.J. Wagner has entered more than 2200 LPIA-occurrences and $>400$ genera of brachiopods, bivalves and gastropods into the PBDB (Appendix 20; download specifically for these clades). Gastropods are overrepresented (>1400 occurrences) in his data, which is also reflected in the number of genera (nearly 250). According to Harper (1998), bivalves (and mollusks in general) are well represented and fossils are well recorded. This is mirrored in the Wagner entries, as a large number of genera would have also been present without his input. This implies that the gastropod and bivalve data record in the PBDB is comparably good. Clapham and his team have enormously increased the amount of available information on brachiopods (especially for the Permian) as can be clearly seen in the graphs. In parts, their entries even triple the record of genera. We postulate that M. Clapham and his team have strongly improved the quality of the PBDB. Accordingly, we have benefitted by working with a more complete dataset that provides us a more comprehensive picture of the past. Hence, we argue that the rise of brachiopods in the Permian is a true ecological signal, and we want to highlight the importance of extensive data entry into the PBDB.

\section{CONCLUSIONS}

1 Diversity throughout the main, glacial phase of the LPIA remained low and stable, as taxa were well adapted to changing climatic and environmental conditions. This stability is mirrored in the low origination, extinction, and turnover rates.

2 Clades in this study show some preferences to certain environments, although with fluctuations throughout the LPIA. However, many genera do not show pronounced affinities.

3 Origination and extinction rates are similar, independent of whether or not environmental affinities are considered. Thus, the environmental factors are of minor importance during the LPIA when investigating turnover throughout the LPIA.

4 Sea-surface temperature and habitat were not the key factors influencing the faunal change; more likely yet undetermined abiotic factors drove genus richness and turnover.

5 Brachiopods were slightly more diverse during most of the LPIA but dominated the Permian. Yet, after the Permian-Carboniferous boundary, bivalves diversified slightly, remaining on a stable niveau while gastropods continuously, if slowly, continued to diversify.

\section{ACKNOWLEDGEMENTS}

We would like to thank our two anonymous reviewers for providing supporting comments to improve the manuscript. We also would like to thank all contributors to the PBDB (especially M.E. Clapham and P.J. Wagner), and W. Kiessling for vivid discussions. The project was supported by the Deutsche Forschungsgemeinschaft (SE 2283/ $2-1$; KO 5382/2-1). This is Paleobiology Database publication number 377 . 


\section{REFERENCES}

Alexander, R.R., Stanton, R.J., and Dodd, J.R. 1993. Influence of sediment grain size on the burrowing of bivalves. Palaios, 8:289-303. https://doi.org/10.2307/3515151

Allmon, W.D. and Martin, R.E. 2014. Seafood through time revisited: the Phanerozoic increase in marine trophic resources and its macroevolutionary consequences. Paleobiology, 40:256287. https://doi.org/10.1666/13065

Alroy, J. 2008. Dynamics of origination and extinction in the marine fossil record. Proceedings of the National Academy of Sciences, 105 (Supplement 1):11536-11542. https://doi.org/ 10.1073/pnas.0802597105

Alroy, J. 2010. Fair sampling of taxonomic richness and unbiased estimation of origination and extinction rates, p. 55-80. In Alroy, J. and Hunt, G. (eds.), Methods in Paleobiology: Paleontological Society Short Course, October 30th, 2010. The Paleontological Society, Papers, 16. https://doi.org/10.1017/S1089332600001819

Alroy, J., Aberhan, M., Bottjer, D.J., Foote, M., Fürsich, F.T., Harries, P.J., Hendy, A.J.W., Holland, S.M., Ivany, L.C., Kiessling, W., Kosnik, M.A., Marshall, C.R., McGowan, A.J., Miller, A.I., Olszewski, T.D., Patzowsky, M.E., Peters, S.E., Villier, L., Wagner, P.J., Bonuso, N., Borkow, P.S., Brenneis, B., Clapham, M.E., Fall, L.M., Ferguson, C.A., Hanson, V.L., Krug, A.Z., Layou, K.M., Leckey, E.H., Nürnberg, S., Powers, C.M., Sessa, J.A., Simpson, C., Tomašových, A., and Visaggi, C.C. 2008. Phanerozoic trends in the global diversity of marine invertebrates. Science, 321:97-100. https://doi.org/10.1126/science.1156963

Antell, G.S., Kiessling, W., Aberhan, M., and Saupe, E.E. 2020. Marine biodiversity and geographic distributions are independent on large scales. Current Biology, 30:115-121. https://doi.org/10.1016/j.cub.2019.10.065

Arapov, J., Ezgeta-Balić, D., Peharda, M., and Ninčević, G. 2010. Bivalve feeding - how and what they eat? Ribarstvo, 68:105-116.

Atkins, D. 1956. Ciliary feeding mechanisms of brachiopods. Nature, 177:706-707. https:// doi.org/10.1038/177706a0

Balseiro, D. and Powell, M.G. 2020. Carbonate collapse and the Late Paleozoic biodiversity crisis. Geology, 48:118-122. https://doi.org/10.1130/G46858.1

Bambach, R.K., Knoll, A.H., and Wang, S.C. 2004. Origination, extinction, and mass depletions of marine diversity. Paleobiology, 30:522-542. https://doi.org/10.1666/00948373(2004)030<0522:OEAMDO>2.0.CO;2

Beauchamp, B. and Baud, A. 2002. Growth and demise of Permian biogenic chert along northwest Pangea: evidence for end-Permian collapse of thermohaline circulation. Palaeogeography, Palaeoclimatology, Palaeoecology, 184:37-63. https://doi.org/10.1016/ S0031-0182(02)00245-6

Benton, M.J. 2009. The Red Queen and the Court Jester: species diversity and the role of biotic and abiotic factors through time. Science, 323:728-732. https://doi.org/10.1126/ science. 1157719

Berner, A.B. 2006. GEOCARBSULF: A combined model for Phanerozoic atmospheric $\mathrm{O}_{2}$ and $\mathrm{CO}_{2}$. Geochimica et Cosmochimica Acta, 70:5653-5664. https://doi.org/10.1016/ j.gca.2005.11.032

Bonelli, J.R. and Patzowksi, M.E. 2008. How are global patterns of faunal turnover expressed at regional stages? Evidence from the Upper Mississippian (Chesterian Series), Illinois Basin, USA. Palaios, 23:760-772. https://doi.org/10.2110/palo.2008.p08-039r

Brett, C.E. 1989. Sequence stratigraphy, paleoecology, and evolution: biotic clues and responses to sea-level fluctuations. Palaios, 13:241-262. https://doi.org/10.2307/3515448

Brett, C.E., Baird, G.C., Berthelomew, A.J., DeSantis, M.K., and Ver Straeten, C.A. 2011. Sequence stratigraphy and a revised sea-level curve for the Middle Devonian of eastern North America. Palaeogeography, Palaeoclimatology, Palaeoecology, 304:21-53. https:// doi.org/10.1016/j.palaeo.2010.10.009

Bullivant, J.S. 1968. The method of feeding of lophophorates (Bryozoa, Phoronida, Brachiopoda). New Zealand Journal of Marine and Freshwater Research, 2:35-146. https:// doi.org/10.1080/00288330.1968.9515231 
Carlson, S.J. 2016. The evolution of Brachiopoda. Annual Review of Earth and Planetary Sciences, 44:409-438. https://doi.org/10.1146/annurev-earth-060115-012348

Chen, B., Joachimski, M.M., Wang, X.-d., Shen, S.-Z., Qi, Y.-p., and Qie W.-k. 2016. Ice volume and paleoclimate history of the Late Paleozoic Ice Age from conodont apatite oxygen isotopes from Naqing (Guizhou, China). Palaeogeography, Palaeoclimatology, Palaeoecology, 448:151-161. https://doi.org/10.1016/j.palaeo.2016.01.002

Cherns, L. and Wright, V.P. 2000. Missing molluscs as evidence of large-scale, early skeletal aragonite dissolution in a Silurian sea. Geology, 28:791-794. https://doi.org/10.1130/00917613(2000)28<791:MMAEOL>2.0.CO;2

Cherns, L. and Wright, V.P. 2009. Quantifying the impacts of early diagenetic aragonite dissolution on the fossil record. Palaios, 24:756-771. https://doi.org/10.2110/palo.2008.p08$134 r$

Cherns, L., Wheeley, J.R., and Wright, V.P. 2008. Taphonomic windows and molluscan preservation. Palaeogeography, Palaeoclimatology, Palaeoecology, 270:220-229. https:// doi.org/10.1016/j.palaeo.2008.07.012

Clapham, M.E. and Bottjer, D.J. 2007. Permian marine paleoecology and its implications for large-scale decoupling of brachiopod and bivalve abundance and diversity during the Lopingian (Late Permian). Palaeogeography, Palaeoclimatology, Palaeoecology, 249:283301. https://doi.org/10.1016/j.palaeo.2007.02.003

Clapham, M.E., Bottjer, D.J., Powers, C.M., Bonuso, N., Fraiser, M.L., Marenco, P.J., Dornbos, S.Q., and Pruss, S.B. 2006. Assessing the ecological dominance of Phanerozoic marine invertebrates. Palaios, 21:431-441. https://doi.org/10.2110/palo.2005.P05-017R

Clark Rhodes, M. and Thompson, R.J 1993. Comparative physiology of suspension-feeding in living brachiopods and bivalves: evolutionary implications. Paleobiology, 19:322-334. https:// doi.org/10.1017/S0094837300000300

Dunhill, A., Hannisdal, B., and Benton, M. 2014. Disentangling rock record bias and commoncause from redundancy in the British fossil record. Nature Communications, 5:4818. https:// doi.org/10.1038/ncomms5818

Eichenseer, K., Balthasar, U., Smart, C.W., Stander, J., Haaga, K.A., and Kiessling, W. 2019. Jurassic shift from abiotic to biotic control on marine ecological success. Nature Geoscience, 12:638-642. https://doi.org/10.1038/s41561-019-0392-9

Fielding, C.R., Frank, T.D., Birgenheier. L.P., Rygel, M.C., Jones, A.T., and Roberts, J. $2008 a$. Stratigraphic imprint of the Late Paleozoic Ice Age in eastern Australia: a record of alternating glacial and nonglacial climate regime. Journal of the Geological Society London, 165:129-140. https://doi.org/10.1144/0016-76492007-036

Fielding, C.R., Frank, T.D., Birgenheier. L.P., Rygel, M.C., Jones, A.T., and Roberts, J. $2008 b$. Stratigraphic record and facies associations of the Late Paleozoic Ice Age in Eastern Australia (New South Wales and Queensland), p. 41-57. In Fielding, C.R., Frank, T.D., and Isbell, J.L. (eds.), Resolving the Late Paleozoic Ice Age in Time and Space. Geological Society of America, Special Paper 441. https://doi.org/10.1130/2008.2441(03)

Fielding, C.R., Frank, T.D., and Isbell, J.L. 2008c. Resolving the Late Paleozoic Ice Age in Time and Space. Geological Society of America, Special Paper 441. 354 p. https://doi.org/10.1130/ 978-0-8137-2441-6

Fielding, C.R., Frank, T.D., and Isbell, J.L. 2008d. The Late Paleozoic Ice Age - a review of current understanding and synthesis of global climate patterns, p.343-354. In Fielding, C.R., Frank, T.D., and Isbell, J.L. (eds.), Resolving the Late Paleozoic Ice Age in Time and Space. Geological Society of America Special, Paper 441. https://doi.org/10.1130/2008.2441(24)

Foote, M. 2000. Origination and extinction components of taxonomic diversity: Paleozoic and post-Paleozoic dynamics. Paleobiology, 26:578-605. https://doi.org/10.1666/00948373(2000)026<0578:oaecot>2.0.co;2

Foote, M. 2003. Origination and extinction through the Phanerozoic: A new approach. Journal of Geology, 111:125-148. https://doi.org/10.1086/345841

Foote, M. 2006. Substrate affinity and diversity dynamics of Paleozoic marine animals. Paleobiology, 32:345-366. https://doi.org/10.1666/05062.1

Füchtbauer, H. 1988. Sedimente und Sedimentgesteine. Schweizerbart, Stuttgart.

Grossman, E.L., Yancey, T.E., Jones, T.E., Bruckschen, P., Chuvashov, B., Mazzullo, S.J., and Mii, H.S. 2008. Glaciation, aridification, and carbon sequestration in the PermoCarboniferous: the isotopic record from low latitudes. Palaeogeography, Palaeoclimatology, Palaeoecology, 268:222-233. https://doi.org/10.1016/j.palaeo.2008.03.053 
Harper, D.A. and Moran, R. 1997. Fossils explained 20: Brachiopod life styles. Geology Today, Nov-Dec:235-238. https://doi.org/10.1046/j.1365-2451.1997.t01-1-00018.x

Harper, E.M. 1998. The fossil record of bivalve molluscs, p. 243-267. In Donovan, S.K. and Paul, C.R.C. (eds.), The Adequacy of the Fossil Record. John Wiley and Sons, Chichester.

Holland, S.M. 2012. Sea level change and the area of shallow-marine habitat: implications for marine biodiversity. Paleobiology, 38:205-217. https://doi.org/10.1666/11030.1

Holland, S.M., Miller, A.I., Meyer, D.L., and Dattilo, B.F. 2001. The detection and importance of subtle biofacies within a single lithofacies: The Upper Ordovician Kope Formation of the Cincinnati, Ohio Region. Palaios, 16:205-217. https://doi.org/10.2307/3515600

Hopkins, M.J. 2014. The environmental structure of trilobite morphological disparity. Paleobiology, 40:352-373. https://doi.org/10.1666/13049

Hopkins, M.J., Simpson, C., and Kiessling, W. 2014. Differential niche dynamics among major marine invertebrate clades. Ecology Letters, 17:314-323. https://doi.org/10.1111/ele.12232

Isbell, J.L., Lenaker, P.A., Askin, R.A., Miller, M.F., and Babcock, L.E. 2003a. Reevaluation of the timing and extent of Late Paleozoic glaciation in Gondwana: role of the Transantarctic Mountains. Geology, 31:977-980. https://doi.org/10.1130/G19810.1

Isbell, J.L., Miller, M.F., Wolfe, K.L., and Lenaker, P.A. 2003b. Timing of Late Paleozoic glaciation in Gondwana: was glaciation responsible for the development of Northern Hemisphere cyclothems? Geological Society of America, Special Papers, 370:5-24. https://doi.org/ 10.1130/0-8137-2370-1.5

Isbell, J.L., Fraiser, M.L., and Henry, L.C. 2008. Examining the complexity of environmental change during the Late Paleozoic and early Mesozoic. Palaios, 23:267-269. https://doi.org/ 10.2110/palo.2008.s03

Jarochowska, E., Ray, D.C., Röstel, P., Worton, G., and Munnecke, A. 2018. Harnessing stratigraphic bias at the section scale: conodont diversity in the Homerian (Silurian) of the Midland Platform, England. Palaeontology, 61:57-76. https://doi.org/10.1111/pala.12326

Jordan, N., Allison, P.A., Hill, J., and Sutton, M.D. 2015. Not all aragonitic molluscs are missing: taphonomy and significance of a unique shelly Lagerstätte from the Jurassic of SW Britain. Lethaia, 48:540-548. https://doi.org/10.1111/let.12126

Kidwell, S.M. 2005. Shell composition has no net impact on large-scale evolutionary patterns in mollusks. Science, 307:914-917. https://doi.org/10.1126/science.1106654

Kiessling, W. and Aberhan, M. 2007. Environmental determinants of marine benthic biodiversity dynamics through Triassic-Jurassic time. Paleobiology, 33:414-434. https://doi.org/10.1666/ 06069.1

Kiessling, W. and Kocsis, Á.T. 2015. Biodiversity dynamics and environmental occupancy of fossil azooxanthellate and zooxanthellate scleractinian corals. Paleobiology, 41:402-414. https://doi.org/10.1017/pab.2015.6

Kiessling, W., Simpson, C., and Foote, M. 2010. Reefs as cradles of evolution and sources of biodiversity in the Phanerozoic. Science, 327:196-198. https://doi.org/10.1126/ science. 1182241

Koch, C.F. and Sohl, N.F. 1983. Preservational effects in paleoecological studies: Cretaceous mollusc examples. Paleobiology, 9:26-34. https://doi.org/10.1017/S0094837300007351

Kocsis, A., Reddin, C.J., Alroy, J., and Kiessling, W. 2019. The R package divDyn for quantifying diversity dynamics using fossil sampling data. Methods in Ecology and Evolution, 10:735743. https://doi.org/10.1111/2041-210x.13161

Kowalewski, M. and Hoffmeister, A.P. 2003. Sieves and fossils: effects of mesh size on paleontological patterns. Palaios, 18:460-469. https://doi.org/10.1669/08831351(2003)018<0460:safeom>2.0.co;2

Lei, Y., Servais, T., and Feng, Q. 2013. The diversity of the Permian phytoplankton. Review of Palaeobotany and Palynology, 198:145-161. https://doi.org/10.1016/j.revpalbo.2013.03.004

Liow, L.H., Reitan, T., and Harnik, P.G. 2015. Ecological interactions on macroevolutionary time scales: clams and brachiopods are more than ships that pass in the night. Ecology Letters, 18:1030-1039. https://doi.org/10.1111/ele.12485

Long, M.C., Deutsch, C., and Ito, T. 2016. Finding forced trends in oceanic oxygen. Global Biochemical Cycles, 30:381-379. https://doi.org/10.1002/2015GB005310

Martin, R.E. and Servais, T. 2020. Did the evolution of the phytoplankton fuel the diversification of the marine biosphere? Lethaia, 53:5-31. https://doi.org/10.1111/let.12343 
Martin, R.E., Quigg, A., and Podkovyrov, V. 2008. Marine biodiversification in response to evolving phytoplankton stoichiometry. Palaeogeography, Palaeoclimatology, Palaeoecology, 258:277-291. https://doi.org/10.1016/j.palaeo.2007.11.003

McGowan, A.J. and Smith, A.B. 2008. Are global Phanerozoic marine diversity curves truly global? A study of the relationship between regional rock records and global marine diversity. Paleobiology, 34:80-103. https://doi.org/10.1666/07019.1

McLachlan, A. 1996. Physical factors in benthic ecology: effects of changing sand particle size on beach fauna. Marine Ecology Progress Series, 131:205-217. https://doi.org/10.3354/ meps 131205

McLaren, D.J. 1982. Frasnian-Famennian extinctions. Geological Society of America, Special Paper, 190:477-484. https://doi.org/10.1130/SPE190-p477

Mii, Hs., Grossman, E.L., and Yancey, T.E. 1999. Carboniferous isotope stratigraphies of North America: implications for Carboniferous paleoceanography and Mississippian glaciation. Geological Society of America, Bulletin, 111:960-973. https://doi.org/10.1130/00167606(1999)111<0960:CISONA>2.3.CO;2

Montañez, I.P. and Poulsen, C.J. 2013. The Late Paleozoic Ice Age: An evolving paradigm. Annual Review of Earth and Planetary Science, 41:629-656. https://doi.org/10.1146/ annurev.earth.031208.100118

Mullins, G.L. and Servais, T. 2008. The diversity of the Carboniferous phytoplankton. Review of Palaeobotany and Palynology, 149:29-49. https://doi.org/10.1016/j.revpalbo.2007.10.002

Muscente, A.D., Prabhu, A., Zhong, H., Eleish, A., Meyer, M.B., Fox, P., Hazen, R.M., and Knoll, A.H. 2018. Quantifying ecological impacts of mass extinctions with network analysis of fossil communities. Proceedings of the National Academy of Sciences 115:5217-5222. https:// doi.org/10.1073/pnas.1719976115

Payne, J.K., Heim, N.A., Knope, M.L., and McClain, C.R. 2014. Metabolic dominance of bivalves predates brachiopod diversity decline by more than 150 million years. Proceedings of the Royal Society B, 281(1783):20133122. https://doi.org/10.1098/rspb.2013.3122

Peters, S. 2008. Environmental determinants of extinction selectivity in the fossil record. Nature Letters, 454:626-629. https://doi.org/10.1038/nature07032

Pörtner, H.O. 2002. Climate variations and the physiological basis of temperature dependent biogeography: systematic to molecular hierarchy of thermal tolerance in animals. Comparative Biochemistry and Physiology Part A: Molecular \& Integrative Physiology, 132:739-761. https://doi.org/10.1016/s1095-6433(02)00045-4

Pörtner, H.O. 2010. Oxygen- and capacity-limitation of thermal tolerance: a matrix for integrating climate-related stressor effects in marine ecosystems. Journal of Experimental Biology, 213:881-893. https://doi.org/10.1242/jeb.037523

Powell, M.G. 2005. Climatic basis for sluggish macroevolution during the Late Paleozoic Ice Age. Geology, 33:381-384. https://doi.org/10.1130/G21155.1

Powell, M.G. 2007. Latitudinal diversity gradients for brachiopod genera during Late Palaeozoic time: links between climate, biogeography and evolutionary rates. Global Ecology and Biogeography, 16:519-528. https://doi.org/10.1111/j.1466-8238.2007.00300.x

R Core Team. 2016. R: A language and environment for statistical computing. R Foundation for Statistical Computing, Vienna, Austria. https://www.R-project.org.

Raup, D.M. and Sepkoski, J.J. 1982. Mass extinctions in the marine fossil record. Science, 215:1501-1503. https://doi.org/10.1126/science.215.4539.1501

Reitan, T. and Liow, L.H. 2017. An unknown Phanerozoic driver of brachiopod extinction rates unveiled by multivariate linear stochastic differential equations. Paleobiology, 43:537-549. https://doi.org/10.1017/pab.2017.11

Richards, F.A. 1957. Chapter 9 - Oxygen in the ocean. Geological Society of America, Memoir, 67:185-238. https://doi.org/10.1130/MEM67V1-p185

Richardson, J.R. 1986. Brachiopods. Scientific American, 255:100-107. https://doi.org/10.1038/ scientificamerican0986-100

Riegel, W. 2008. The Late Palaeozoic phytoplankton blackout - artefact or evidence of global change? Review of Palaeobotany and Palynology, 148:73-90. https://doi.org/10.1016/ j.revpalbo.2006.12.006

Rigby, S. and Milsom, C.V. 2000. Origin, evolution, and diversification of zooplankton. Annual Review of Ecology and Systematics, 31:293-313. https://doi.org/10.1146/ annurev.ecolsys.31.1.293 
Roden, V.J., Hausmann, I.M., Nützel, A., Seuss, B., Reich, M., Urlichs, M., Hagdorn, H., and Kiessling, W. 2020. Fossil liberation: a model to explain high biodiversity in the Triassic Cassian Formation. Palaeontology, 63:85-102. https://doi.org/10.1111/pala.12441

Rojas, A., Catalayud, J., Kowalewski, M., Neuman, M., and Rosval, M. 2019. Low-latitude origins of the four Phanerozoic Evolutionary Faunas. BioRxiv (preprint). https://www.biorxiv.org/ content/10.1101/866186v2.full

Sepkoski, J.J. 1981. A factor analytic description of the Phanerozoic marine fossil record. Paleobiology, 7:36-53. https://doi.org/10.1017/S0094837300003778

Sepkoski, J.J. 1984. A kinetic model of Phanerozoic taxonomic diversity. III. Post-Paleozoic families and mass extinctions. Paleobiology, 10:246-267. https://doi.org/10.1017/ S0094837300008186

Sepkoski, J.J. 1990. 1.6 Evolutionary faunas, p. 37-41. In Briggs, D.E.G. and Crowther, P.R. (eds.), Paleobiology. A Synthesis. Blackwell, Oxford.

Sepkoski, J.J. 1998. Rates of speciation in the fossil record. Philosophical Transactions of the Royal Society of London B, 353:315-326. https://doi.org/10.1098/rstb.1998.0212

Servais, T. 2015. No 'phytoplankton blackout' in the Late Paleozoic. Geological Society of America Abstracts with Programs, Baltimore, Maryland. Paper No. 18-3.

Servais, T., Nützel, A., and Mullins, G. 2006. Was there a phytoplankton blackout in the Late Paleozoic? Palynology, 30:228. https://doi.org/10.1080/01916122.2006.9989627

Seuss, B., Nützel, A., Mapes, R.H., and Yancey, T.E. 2009. Facies and fauna of the Pennsylvanian Buckhorn Asphalt Quarry deposit: A review and new data on an important Palaeozoic fossil Lagerstätte with aragonite preservation. Facies, 55:609-645. https://doi.org/ 10.1007/s10347-009-0181-9

Shiino, Y. 2010. Passive feeding in spiriferide brachiopods: An experimental approach using models of Devonian Paraspirifer and Cyrtospirifer. Lethaia, 43:223-231. https://doi.org/ 10.1111/j.1502-3931.2009.00185.x

Shiino, Y., Kuwazuru, O., and Yoshikawa, N. 2009. Computational fluid dynamics simulations on a Devonian spiriferid Paraspirifer bownockeri (Brachiopoda): generating mechanism of passive feeding flows. Journal of Theoretical Biology, 259:132-141. https://doi.org/10.1016/ j.jtbi.2009.02.018

Song, H., Wignall, P.B., Song, H., Dai, X., and Chu, D. 2019. Seawater temperature and dissolved oxygen over the past 500 million years. Journal of Earth Sciences, 30:236-243. https://doi.org/10.1007/s12583-018-1002-2

Stanley, S.M. 2007. An analysis of the history of marine animal diversity. Paleobiology, 33:1-55. https://doi.org/10.1666/06020.1

Stanley, S.M. and Powell, M.G. 2003. Depressed rates of origination and extinction during the Late Paleozoic Ice Age: a new state for the global marine ecosystem. Geology, 31:877-880. https://doi.org/10.1130/G19654R.1

Stramma, L., Johnson, G.C., Sprintall, J., and Mohrholz, V. 2008. Expanding oxygen-minimum zones in the tropical oceans. Science, 320:655-658. https://doi.org/10.1126/science.1153847

Wignall, P.B. and Simms, M.J. 1990. Pseudoplankton. Palaeontology, 33:359-378.

Wright, V.P. and Cherns, L. 2004. Are there "black holes" in carbonate deposystems? Geologica Acta, 2:285-290. https://doi.org/10.1344/105.000001420

Wright, V.P. and Cherns, L. 2008. The subtle thief: selective dissolution of aragonite during shallow burial and the implications for carbonate sedimentology. SEPM Special Publication, 89: 47-54. https://doi.org/10.2110/pec.08.89.0047

Wright, V., Cherns, L., and Hodges, P, 2003. Missing molluscs: field testing taphonomic loss in the Mesozoic through early large-scale aragonite dissolution. Geology, 31:211-214. https:// doi.org/10.1130/0091-7613(2003)031<0211:MMFTTL>2.0.CO;2

Yasuhara, M., Cronin, T.M., deMenocal., P.B., Okahashi, H., and Linsley, B.K. 2008. Abrupt climate change and collapse of deep-sea ecosystems. Proceedings of the National Academy of Sciences, 105:1556-1560. https://doi.org/10.1073/pnas.0705486105 


\section{APPENDICES}

All the appendices are supplied in zipped files at https://palaeo-electronica.org/content/2020/ 3104-biodiversity-across-the-Ipia. Appendices 1-3, 5-20 are in one zipped file, and Appendix 4 in a separate file.

\section{APPENDIX 1.}

PBDB list of occurrences, extended with own datasets, used for the analyses.

\section{APPENDIX 2.}

List of lithologies in the PBDB datasheet subdivided into four categories; lithologies as present in the PBDB. Categories: carbonates (Karbonatgesteine sensu Füchtbauer, 1988), clastics (Siliziklastika sensu Füchtbauer, 1988), fine-grained (Ton- und Siltsteine sensu Füchtbauer, 1988); categories extended to include as many lithologies as possible. Excluded are lithologies that either show strong diagenesis (e.g., chert, coal), contain unprecise information (e.g., sediments or "not reported"), are mixed deposits (e.g., breccia, conglomerate), or represent lithologies that do not fit into any category (e.g., phosphorite or ironstone). Lithological groupings used for this study are "carbonates" and "siliciclastics" (siliciclastics comprise clastics and fine-grained).

\section{APPENDIX 3.}

Code for the statistical analyses performed in $\mathrm{R}$.

\section{APPENDIX 4.}

Phanerozoic dataset for brachiopods, bivalves, and gastropods.

\section{APPENDIX 5.}

List of reference numbers of Clapham-authorizations in the PBDB for bivalves, gastropods, and brachiopods.

\section{APPENDIX 6.}

Overview of number of occurrences (6.A), origination (6.B) and extinction (6.C) rates for the LPIA; brachiopods, bivalves, and gastropods as well as clades combined are plotted. Mean seasurface temperature (SST) after Song et al. (2019).

\section{APPENDIX 7.}

Genus richness (CSIB) for during the LPIA plotted by affinity. Mean sea-surface temperature (SST) after Song et al. (2019). 


\section{APPENDIX 8.}

Origination rates of clades in different environmental settings throughout the LPIA. Mean seasurface temperature (SST) after Song et al. (2019).

\section{APPENDIX 9.}

Origination rates of clades in different environmental settings throughout the LPIA; paired by setting (9A: carbonate vs. siliciclastic; 9B: shallow vs. deep; 9C: fine vs. coarse; 9D: reef vs. nonreef). Mean sea-surface temperature (SST) after Song et al. (2019).

\section{APPENDIX 10.}

Extinction rates of clades in different environmental settings throughout the LPIA. Mean sea-surface temperature (SST) after Song et al. (2019).

\section{APPENDIX 11.}

Extinction rates of clades in different environmental settings throughout the LPIA; paired by setting (11A: carbonate vs. siliciclastic; 11B: shallow vs. deep; 11C: fine vs. coarse; 11D: reef vs. non-reef). Mean sea-surface temperature (SST) after Song et al. (2019).

\section{APPENDIX 12.}

Turnover rates for the compared environments paired by setting: carbonate vs. siliciclastic, reef vs. non-reef, shallow vs. deep, fine vs. coarse; including the newly reconstructed sea-surface temperature (SST) after Song et al. (2019).

\section{APPENDIX 13.}

Sampling completeness for the clades in the Late Paleozoic Ice Age, comprising the Famennian to Wuchiapingian.

\section{APPENDIX 14.}

Number of references in the PBDB during the LPIA for brachiopods, bivalves and gastropods. Mean sea-surface temperature (SST) after Song et al. (2019).

\section{APPENDIX 15.}

Table of correlations (Spearman's rank correlation coefficient) between occurrences, genus richness, and subsampled genus richness versus references per stage in the PBDB.

\section{APPENDIX 16.}

Proportion of references per clade among total references. 


\section{APPENDIX 17.}

Number of occurrences with (thick lines) and without (thin lines) Clapham-authorized entries; including the newly reconstructed sea-surface temperature (SST) after Song et al. (2019).

\section{APPENDIX 18.}

Subsampled genus richness (CSIB) with (thick lines) and without (thin lines) Clapham-authorized entries; including the newly reconstructed sea-surface temperature (SST) after Song et al. (2019).

\section{APPENDIX 19.}

Subsampled SQS genus richness (CSIB) with (thick lines) and without (thin lines) Claphamauthorized entries; including the newly reconstructed sea-surface temperature (SST) after Song et al. (2019).

\section{APPENDIX 20.}

Occurrence download for brachiopods, bivalves and gastropods for the LPIA with P. Wagner as enterer. 